\title{
Serum protein concentrations, including acute phase proteins, in calves experimentally infected with Salmonella Dublin ${ }^{1}$
}

\author{
Daniela Gomes da Silva ${ }^{2}$, Péricles Ricardo Lacerda e Silva ${ }^{2}$, Paulo César da Silva ${ }^{2}$ \\ and José Jurandir Fagliari ${ }^{2}$
}

\begin{abstract}
Silva D.G., Silva P.R.L., Silva, P.C. \& Fagliari J.J. 2011. [Serum protein concentrations, including acute phase proteins, in calves experimentally infected with SalmoneIla Dublin.] Pesquisa Veterinária Brasileira 31(7):551-554. Departamento de Clínica e Cirurgia Veterinária, Faculdade de Ciências Agrárias e Veterinárias, Universidade Estadual Paulista, Via de Acesso Prof. Paulo Donato Castellane s/n, Jaboticabal, SP 14884-900, Brazil. E-mail: danielafcav@yahoo.com.br

The aim of this study was to evaluate serum protein concentrations in calves experimentally inoculated with Salmonella Dublin. Twelve healthy 10 to 15-day-old Holstein calves were randomly allotted into two groups, control and infected with $10^{8} \mathrm{CFU}$ of Salmonella Dublin orally. The calves were subjected to physical evaluation and blood samples were collected shortly before administration of the bacteria and also 24, 48, 72, 96, 120 and 168 hours post-infection. The concentration of serum proteins was determined through sodium dodecyl sulphatepolyacrylamide gel electrophoresis (SDS-PAGE). Thirty serum proteins ranging from molecular weight of 24,000 Da to molecular weight of 236,000 Da were detected. Serum concentrations of ceruloplasmin $(125,000 \mathrm{Da})$, haptoglobin $(45,000 \mathrm{Da})$, acid glycoprotein $(40,000 \mathrm{Da})$ and a 34,000 Da protein were significantly increased in the experimentally infected calves, when compared with their concentrations in the control animals. Therefore, this study showed that $S$. Dublin infection could lead to the increase of certain serum proteins in calves.
\end{abstract}

INDEX TERMS: Salmonella Dublin, SDS-PAGE, serum proteins, calves.

RESUMO.- [Teores séricos de proteínas, incluindo proteínas de fase aguda, em bezerros infectados experimentalmente com Salmonella Dublin.] 0 objetivo do estudo foi avaliar as concentrações séricas de proteínas em bezerros inoculados experimentalmente com Salmonella Dublin. Foram examinados 12 bezerros sadios da raça Holandesa com 10 a 15 dias de idade, distribuídos aleatoriamente em dois grupos, controle e infectado experimentalmente com $10^{8}$ UFC de Salmonella Dublin. As amostras de sangue foram colhidas minutos antes e 12, 24, 48, 72, 96, 120 e 168 horas após a inoculação. As concentrações séricas das proteínas ceruloplasmina (125.000 Da), haptoglobina (45.000 Da), glicoproteína ácida (40.000 Da) e proteína de peso molecular de $34.000 \mathrm{Da}$ foram significativamente maiores nos bezerros infectados do que nos do grupo controle. Portanto, o estudo

\footnotetext{
${ }^{1}$ Received on September 20, 2010.

Accepted for publication on February 24, 2011.

2 Departamento de Clínica e Cirurgia Veterinária, Faculdade de Ciências Agrárias e Veterinárias (FCAV), Universidade Estadual Paulista (Unesp), Via de Acesso Prof. Paulo Donato Castellane s/n, Jaboticabal, SP 14884900, Brazil. *Corresponding author: danielafcav@yahoo.com.br
}

mostrou que a infecção por $S$. Dublin pode elevar a concentração de certas proteínas séricas em bezerros.

TERMOS DE INDEXAC̄̃̃O: Salmonella Dublin, SDS-PAGE, proteínas séricas, bezerros.

\section{INTRODUCTION}

Salmonellosis is one of the main causes of morbidity and mortality in calves (Smith et al. 1994). Although the cattle may be infected by several serovars of Salmonella, Salmonella Dublin and Salmonella Typhimurium are the most prevalent serovars isolated from calves with clinical salmonellosis (Smith et al. 1989, Santos et al. 2002). After oral infection, the bacteria colonize the digestive system causing cellular injury, mainly in the epithelium of the colon and ileum (Kirk et al. 2002). Once it reaches the lamina propria of the bowel wall, Salmonella induces a remarkable inflammatory reaction characterized by intense infiltrate of polimorphonuclear cells and fluid secretion into the intestinal lumen (Wallis et al. 1995). Calves with 1 to 6 weeks of age are the most susceptible to $S$. Dublin infection which is frequently characterized by fever, diarrhea, bacteremia and respiratory 
signs (Wray \& Davies 2000, Veling et al. 2002). Classically, these signs have been useful in monitoring the evolution of the disease; however, changes in these parameters are difficult to quantify (Deignan et al. 2000). Because of the inflammatory process, salmonellosis leads to changes in serum concentrations of acute phase proteins (Heinrich et al. 1990, Kent 1992) that could be identified by means of electrophoresis (Kaneko et al. 2008). Since acute phase proteins increase more rapidly after the onset of inflammation, in response to inflammatory cytokines, the identification of changes in serum concentrations of these proteins might be useful to detect the early stage of infection and to monitor the progression of salmonellosis. Sodium dodecyl sulphate-polyacrylamide gel electrophoresis (SDSPAGE) has been widely used to evaluate the acute phase proteins of the inflammatory response, contributing to the diagnosis and prognosis of several diseases, as equine laminits (Fagliari et al. 1998), equine acute abdomen (Fagliari \& Silva 2002), pneumonia in calves (Fagliari et al. 2003) and mastitis in ewes (Costa et al. 2010). However, there is no previous report on the use of SDS-PAGE to measure serum proteins changes in calves with salmonellosis.

Therefore, the aim of the study was to determine, by means of SDS-PAGE, whether serum protein concentrations were altered in calves experimentally infected with Salmonella Dublin, with special regard to acute phase proteins.

\section{MATERIALS AND METHODS}

Blood samples from twelve healthy 10 to 15 -day-old Holstein calves, obtained from a dairy farm that had no history of salmonella isolations, were evaluated. During the experimental period the calves were housed in individual stalls with fenestrated plastic floor $(1.30 \mathrm{~m} \times 1.50 \mathrm{~m} \times 1.35 \mathrm{~m})$ suspended $0.4 \mathrm{~m}$ above the ground and located in an isolated area with concrete floor of the Laboratório de Apoio à Pesquisa do Departamento de Clínica e Cirurgia Veterinária. The calves were bedded on rubber floor and received four liters of pasteurized milk, twice a day, and were fed ration and water ad libitum. The Institutional Ethics and Animal Welfare Commission from FCAV/UNESP (CEBEA) approved this study (Protocol 01359706). During the experimental period, the cleaning and desinfection of bucktes and stalls was performed twice a day with detergent and $2.5 \%$ sodium hypochlorite solution.

Prior to experimental exposure, only animals that had normal blood counts ${ }^{3}$, negative cultures for salmonella and no fever were randomly allocated in two groups: control and infected. Calves from control group $(\mathrm{n}=6)$ received orally $10 \mathrm{~mL}$ of Brain Heart Infusion (BHI) broth ${ }^{4}$ through a plastic syringe before the first milk intake, whereas calves from the infected group $(n=6)$ were challenged orally with $10^{8}$ colony-forming unit (CFU) of Salmonella Dublin suspended in $10 \mathrm{~mL}$ of BHI broth (Fecteau et al. 2003). Infected calves were housed in a separated area from control calves to avoid cross contamination between groups.

Salmonella Dublin samples (register IOC 3101/03) used for the preparation of the inoculum (Miles \& Misra 1938, Wray \& Sojka 1981) were originally isolated from feces of infected calves during

\footnotetext{
${ }^{3}$ CC-530, CELM, Barueri, São Paulo, Brazil.

${ }^{4}$ CM0225, Oxoid, Basingstoke, Hampshire, England.

${ }^{5}$ Labtest, Labtest Diagnóstica, Lagoa Santa, MG, Brazil.

${ }^{6}$ Labquest, Labtest Diagnóstica, Lagoa Santa, MG, Brazil.

${ }^{7}$ Shimadzu CS 9301, Shimadzu Corporation, Tokyo, Japan.

${ }^{8}$ Sigma Chemical Company, St Louis, MO, USA.
}

the natural outbreak of salmonellosis and were donated by Fundação Oswaldo Cruz (Manguinhos/RJ, Brazil).

Blood samples were collected by venopunction before inoculation of BHI with or without Salmonella Dublin, and 24, 48, 72, 96, 120 and 168 hours later. Blood samples were centrifuged, and serum was obtained and frozen until being analyzed. During each collection, a physical examination was performed (Dirksen et al. 1993). The isolation of Salmonella Dublin was made from samples collected with rectal swabs (Rice et al. 1997, Santos et al. 2002). The PCR assay was also used for detection of the bacteria (Itoh et al. 1997).

Total serum protein concentrations were determined by the Biuret Method with a commercial kit ${ }^{5}$ and the changein optical density was read by spectrophotometry ${ }^{6}$. Serum proteins were fractionated by means of sodium dodecyl sulphate-polyacrylamide gel electrophoresis SDS-PAGE) (Weber \& Osborn 1969). Concentration of protein fractions was determined by use of computerassisted densitometry ${ }^{7}$. Proteins were identified by means of reference markers ${ }^{8}$ with molecular weights of 24,000 Da, 29,000 Da, 36,000 Da, 45,000 Da, 55,000 Da, 66,000 Da, 97,000 Da, $116,000 \mathrm{Da}$ and $205,000 \mathrm{Da}$, and by comparison with the electrophoretic mobility of purified albumin, transferrin, ceruloplasmin, $\alpha_{1}$-antitrypsin, haptoglobin and immunoglobin $\mathrm{G}^{7}$.

The data obtained were analyzed by use of ANOVA for repeated measures. Means were compared by Tukey's test. A value of $\mathrm{P}<0.05$ was considered significant (ZAR 1999).

\section{RESULTS}

About 24 to 96 hours after experimental infection, the calves inoculated with $10^{8} \mathrm{CFU}$ of Salmonella Dublin showed clinical signs of salmonellosis, characterized by severe diarrhea, dehydration and fever (Veling et al. 2002), and the bacteria was isolated from rectal samples collected on swabs and detected by PCR. In animals from the control group, no clinical alteration was observed, and cultures and PCR for detection of Salmonella were negative. Control calves also had normal blood counts during the experiment.

Total serum protein concentration from control and infected group were similar (Table 1). Serum protein concentrations obtained by SDS-PAGE allowed to detect 30 proteins with molecular weights ranging from 24,000 Da to 236,000 Da. From these, 8 proteins were submitted to statistical analysis due to their importance for the diagnosis and evidence of difference between the control and infected groups. Twenty-four hours after Salmonella Dublin inoculation, the proteins with molecular weights $125,000 \mathrm{Da}$ (ceruloplasmin), 45,000 Da (haptoglobin), 40,000 Da (acid glycoprotein) and 34,000 Da were increased in animals of the infected group (Table 1). From 0 to 72 hours after the inoculation of Salmonella Dublin, proteins that showed the highest concentration increase was ceruloplasmin $(16 \%$, $110 \%$ and $182 \%$, respectively), and the proteins with molecular weight 34,000 Da $(88 \%, 226 \%$ and $216 \%$, respectively), compared with the baseline concentration in this group (Table 1, Fig.1). Ninety-six hours after experimental infection, the protein with molecular weight $40,000 \mathrm{Da}$ (acid glycoprotein) showed a significant increase (72\%), compared with the control group (Table 1, Fig.1). From 96 to 168 hours after inoculation, the protein of molecular weight 34,000 Da showed the highest increase $(251 \%$ to $277 \%$, respectively) in animals from group 2 (Table 1, Fig.1). 
Table 1. Serum protein concentrations (mean \pm SD), determined by means of sodium dodecyl sulphate-polyacrylamide gel electrophoresis (SDS-PAGE), in healthy calves (Group 1) and in calves with experimental induced infection with Salmonella Dublin (Group 2) before and after Salmonella Dublin inoculation

\begin{tabular}{|c|c|c|c|c|c|c|c|}
\hline \multirow{2}{*}{$\begin{array}{c}\text { Protein and/or molecular } \\
\text { weight (MW) and Group (G) }\end{array}$} & \multicolumn{7}{|c|}{ Time after Salmonella Dublin inoculation } \\
\hline & Oh & $24 \mathrm{~h}$ & $48 \mathrm{~h}$ & $72 \mathrm{~h}$ & $96 \mathrm{~h}$ & $120 \mathrm{~h}$ & $168 \mathrm{~h}$ \\
\hline \multicolumn{8}{|l|}{ Total serum protein (g/dL) } \\
\hline G1 & $6.60 \pm 0.66^{\mathrm{Aa}}$ & $6.53 \pm 0.63^{\mathrm{Aa}}$ & $6.54 \pm 0.48^{\mathrm{Aa}}$ & $6.66 \pm 0.52^{\mathrm{Aa}}$ & $6.62 \pm 0.41^{\mathrm{Aa}}$ & $6.63 \pm 0.45^{\text {Аа }}$ & $6.54 \pm 0.39^{\text {Аа }}$ \\
\hline G2 & $6.56 \pm 0.72^{\mathrm{Aa}}$ & $6.49 \pm 0.76^{\mathrm{Aa}}$ & $6.47 \pm 0.48^{\mathrm{Aa}}$ & $6.44 \pm 0.47^{\mathrm{Aa}}$ & $6.25 \pm 0.45^{\mathrm{Aa}}$ & $6.26 \pm 0.49^{\text {Аа }}$ & $6.52 \pm 0.28^{\mathrm{Aa}}$ \\
\hline \multicolumn{8}{|c|}{ Ceruloplasmin (MW 125,000; mg/dL) } \\
\hline G1 & $18.8 \pm 5.07^{\mathrm{Aa}}$ & $19.0 \pm 4.89 \mathrm{Aa}$ & $17.7 \pm 5.37^{\mathrm{Aa}}$ & $18.0 \pm 4.66^{\mathrm{Aa}}$ & $18.4 \pm 5.07^{\mathrm{Aa}}$ & $17.8 \pm 4.28 \mathrm{Aa}$ & $18.2 \pm 4.71^{\mathrm{Aa}}$ \\
\hline G2 & $18.9 \pm 6.97^{\mathrm{Aa}}$ & $22.0 \pm 5.28^{\mathrm{Aa}}$ & $40.1 \pm 6.72^{\mathrm{Bb}}$ & $53.6 \pm 5.96^{\mathrm{Bc}}$ & $50.1 \pm 8.39^{\mathrm{Bc}}$ & $45.1 \pm 9.74^{\mathrm{Bb}}$ & $23.7 \pm 7.41^{\mathrm{Ba}}$ \\
\hline \multicolumn{8}{|l|}{ Transferrin (MW 81,000; mg/dL) } \\
\hline G1 & $318 \pm 72^{\mathrm{Aa}}$ & $326 \pm 51^{\text {Aa }}$ & $332 \pm 68^{\text {Аа }}$ & $321 \pm 60^{\mathrm{Aa}}$ & $315 \pm 54^{\mathrm{Aa}}$ & $320 \pm 65^{\mathrm{Aa}}$ & $328 \pm 59$ Аа \\
\hline G2 & $331 \pm 90^{\text {Aa }}$ & $313 \pm 67^{\text {Аа }}$ & $314 \pm 86^{\text {Aa }}$ & $310 \pm 71^{\text {Aa }}$ & $329 \pm 97^{\text {Аа }}$ & $312 \pm 95^{\text {Aa }}$ & $287 \pm 89^{\text {Aa }}$ \\
\hline \multicolumn{8}{|l|}{ Albumin (MW 65,000; mg/dL) } \\
\hline G1 & $4,047 \pm 232^{\text {Аа }}$ & $3,953 \pm 152^{\mathrm{Aa}}$ & $3,968 \pm 165^{\mathrm{Aa}}$ & $3,999 \pm 172^{\text {Аа }}$ & $4,010 \pm 201^{\mathrm{Aa}}$ & $3,976 \pm 193^{\text {Аа }}$ & $4,033 \pm 203^{\text {Аа }}$ \\
\hline G2 & $3,909 \pm 265^{\mathrm{Aa}}$ & $3,806 \pm 268^{\mathrm{Aa}}$ & $3,854 \pm 289^{\mathrm{Aa}}$ & $3,873 \pm 337^{\mathrm{Aa}}$ & $3,750 \pm 153^{\mathrm{Ba}}$ & $3,702 \pm 186^{\mathrm{Bb}}$ & $3,668 \pm 196^{\mathrm{Bb}}$ \\
\hline \multicolumn{8}{|c|}{ IgG heavy chain (MW 57,000; mg/dL) } \\
\hline G1 & $1,155 \pm 268^{\mathrm{Aa}}$ & $1,157 \pm 316^{\mathrm{Aa}}$ & $1,151 \pm 317^{\mathrm{Aa}}$ & $1,166 \pm 285^{\text {Аа }}$ & $1,130 \pm 260^{\mathrm{Aa}}$ & $1,124 \pm 218^{\mathrm{Aa}}$ & $1,022 \pm 176^{\text {Aa }}$ \\
\hline G2 & $1,156 \pm 340^{\mathrm{Aa}}$ & $1,105 \pm 343^{\mathrm{Aa}}$ & $1,098 \pm 295^{\text {Аа }}$ & $1,079 \pm 300^{\mathrm{Aa}}$ & $1,006 \pm 288^{\mathrm{Aa}}$ & $1,039 \pm 326^{\text {Aa }}$ & $1,167 \pm 199^{\mathrm{Aa}}$ \\
\hline \multicolumn{8}{|l|}{ Haptoglobin (MW 45,000; mg/dL) } \\
\hline G1 & $70.4 \pm 12.3^{\mathrm{Aa}}$ & $67.3 \pm 11.7^{\mathrm{Aa}}$ & $71.9 \pm 13.0^{\mathrm{Aa}}$ & $66.8 \pm 10.6^{\mathrm{Aa}}$ & $64.3 \pm 11.7^{\mathrm{Aa}}$ & $68.9 \pm 13.4^{\mathrm{Aa}}$ & $72.1 \pm 12.8^{\mathrm{Aa}}$ \\
\hline G2 & $68.5 \pm 10.1^{\mathrm{Aa}}$ & $72.5 \pm 11.3^{\mathrm{Aa}}$ & $88.6 \pm 11.8^{\mathrm{Bb}}$ & $97.9 \pm 10.3^{\mathrm{Bb}}$ & $123 \pm 15.4^{\mathrm{Bc}}$ & $108 \pm 13.6^{\mathrm{Bc}}$ & $99.4 \pm 12.5^{\mathrm{Bb}}$ \\
\hline \multicolumn{8}{|c|}{ Acid glycoprotein (MW 40,000; mg/dL) } \\
\hline G1 & $26.2 \pm 5.4^{\mathrm{Aa}}$ & $29.0 \pm 6.1^{\text {Аа }}$ & $27.6 \pm 5.2^{\mathrm{Aa}}$ & $30.4 \pm 4.9^{\mathrm{Aa}}$ & $28.6 \pm 5.4^{\mathrm{Aa}}$ & $26.0 \pm 4.3^{\text {Аа }}$ & $28.4 \pm 6.2^{\mathrm{Aa}}$ \\
\hline G2 & $28.5 \pm 6.2^{\mathrm{Aa}}$ & $30.1 \pm 6.5^{\text {Aab }}$ & $32.3 \pm 6.1^{\mathrm{Aab}}$ & $35.1 \pm 5.7^{\mathrm{Ab}}$ & $48.3 \pm 6.0^{\mathrm{Bc}}$ & $50.7 \pm 7.8^{\mathrm{Bc}}$ & $54.4 \pm 8.2^{\mathrm{Bc}}$ \\
\hline \multicolumn{8}{|c|}{ No identified protein (MW 34,000; mg/dL) } \\
\hline G1 & $7.18 \pm 3.87^{\mathrm{Aa}}$ & $8.19 \pm 5.59$ Аа & $8.31 \pm 4.05^{\mathrm{Aa}}$ & $8.20 \pm 4.42^{\mathrm{Aa}}$ & $7.58 \pm 5.06^{\mathrm{Aa}}$ & $6.40 \pm 5.38^{\mathrm{Aa}}$ & $8.45 \pm 2.54^{\mathrm{Aa}}$ \\
\hline G2 & $7.92 \pm 3.44^{\mathrm{Aa}}$ & $15.1 \pm 4.34^{\mathrm{Bb}}$ & $26.1 \pm 5.65^{\mathrm{Bc}}$ & $25.3 \pm 4.95^{\mathrm{Bc}}$ & $28.1 \pm 5.78^{\mathrm{Bc}}$ & $31.1 \pm 6.37^{\mathrm{Bc}}$ & $30.2 \pm 6.07^{\mathrm{Bc}}$ \\
\hline \multicolumn{8}{|l|}{ IgG light chain (MW 31,000; mg/dL) } \\
\hline G1 & $460 \pm 244^{\mathrm{Aa}}$ & $483 \pm 212^{\text {Аа }}$ & $478 \pm 192^{\text {Аа }}$ & $450 \pm 222^{\text {Аа }}$ & $456 \pm 204^{\mathrm{Aa}}$ & $467 \pm 183^{\text {Аа }}$ & $445 \pm 154^{\mathrm{Aa}}$ \\
\hline G2 & $438 \pm 201^{\mathrm{Aa}}$ & $442 \pm 195^{\text {Аа }}$ & $463 \pm 202^{\text {Аа }}$ & $442 \pm 198^{\mathrm{Aa}}$ & $466 \pm 211^{\text {Аа }}$ & $440 \pm 189^{\text {Аа }}$ & $451 \pm 193^{\text {Аа }}$ \\
\hline
\end{tabular}

Means followed by the same capital letters in the column and lower case letters in the line do not differ statistically by Tukey's test (P>0.05).

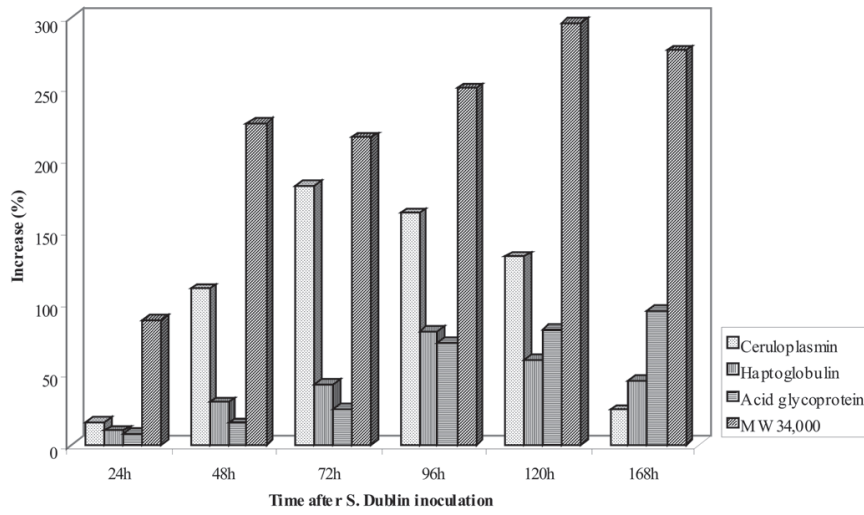

Fig.1. Percentage increase in acute phase protein concentrations, compared with baseline concentrations, in calves experimentally infected with Salmonella Dublin (Group 2).

\section{DISCUSSION}

The proteinogram obtained by sodium dodecyl sulphatepolyacrylamide gel electrophoresios (SDS-PAGE) allowed to detect 30 different proteins, while in other studies (Keay \& Doxey 1982, Fagliari et al. 1991), using agarose gel and cellulose acetate, only 5 to 7 proteins were identified.

In the calves experimentally infected with Salmonella Dublin, serum concentrations of ceruloplasmin, haptoglobin, acid glycoprotein and protein with molecular weight of 34,000 Da increased 24 hours after Salmonella Dublin inoculation. Ceruloplasmin, haptoglobin, acid glycoprotein, and probably protein with molecular weight of $34,000 \mathrm{Da}$ have been identified as acute phase proteins (APP) (Gruys et al. 1994, Godson et al. 1996), and are synthesized through the liver in response to inflammatory cytokines, particularly interleukin-6 (Heinrich et al. 1990). Haptoglobin has been identified as the main acute phase protein in cattle and is an important marker of bacterial infection (Eckersall \& Conner 1988). The increase in serum APP indicated that an inflammatory response had developed in the early stage of experimentally induced Salmonella Dublin infection.

However, Ávila (2009) found only a significant increase in serum concentration of acid glycoprotein in calves experimentally infected with $10^{9} \mathrm{CFU}$ of $S$. Typhimurium, and Garcia (2010) observed significant increase in levels of transferrin, haptoglobin and proteins with molecular weights of 99,000 and 90,000 Da after inoculation of chickens with $10^{8} \mathrm{CFU}$ of $S$. Gallinarum.

These results suggest that the inflammatory response to Salmonella infections depends on the serotype and animal species.

\section{CONCLUSION}

The present investigation showed a significant increase of serum proteins in calves experimentally infected with Salmonella Dublin. Such findings encourage further studies about the use of proteinogram to better characterize Salmonella infections in cattle. In this sense, the effect of the serotype and the number of infecting organisms should lead to important information towards the understanding of salmonellosis in cattle. 
Acknowledgments.- To FAPESP for the financial support and scholarships and also Fundação Oswaldo Cruz for providing the Salmonella Dublin strain.

\section{REFERENCES}

Ávila L.G. 2009. Estudo clínico, laboratorial e terapêutico da diarréia experimental em bezerros induzida por Salmonella enterica subespécie enterica sorotipo Typhimurium. Dissertação de Mestrado em Clínica Médica Veterinária, Faculdade de Ciências Agrárias e Veterinárias, Universidade Estadual Paulista, Jaboticabal, SP. 97p.

Costa N.A., Simão L.C.V., Santos R.A., Afonso J.A.B., Fagliari J.J., Cardoso E.C., Soares P.C. \& Mendonça C.L. 2010. Proteinograma e teores de cobre, ferro e zinco no soro sanguíneo de ovelhas da raça Santa Inês com mastite experimental por Staphylococcus aureus. Pesq. Vet. Bras. 30:435-442.

Deignan T., Alwan A., Kelly J., McNair J., Warrens T. \& O’Farrelly C.O. 2000. Serum haptoglobin: An objective indicator of experimentally-induced Salmonella infections in calves. Res. Vet. Sci. 69:153-158.

Dirksen G., Gründer H.D. \& Stöber M. 1993. Rosenberger, Exame Clínico dos Bovinos. 3a ed. Guanabara Koogan, Rio de Janeiro. 419p.

Eckersall P.D. \& Conner J.G. 1988. Bovine and canine acute phase proteins. Vet. Res. Commun. 12:169-178.

Fagliari J.J., Okuda H.T., Passipieri M. \& Curi P.R. 1991. Serum protein levels of Guzerá cattle in different ages. Arq. Bras. Med. Vet. Zootec. 43:39-60.

Fagliari J.J., McClenahan D., Evanson O.A. \& Weiss D.J. 1998. Changes in plasma protein concentrations in poneis with experimentally induced alimentary laminitis. Am. J. Vet. Res. 59:1234-1237.

Fagliari J.J. \& Silva S.L. 2002. Hemogram and plasma proteins of healthy horses and horses with acute abdomen before and after laparotomy. Arq. Bras. Med. Vet. Zootec. 54:559-567.

Fagliari J.J., Weiss D.J., McClenahan D. \& Evanson O.A. 2003. A serum protein concentrations in calves experimentally induced pneumonic pasteurellosis. Arq. Bras. Med. Vet. Zootec. 55:383-387.

Fecteau M.V., House J.K., Kotarski S.F., Tankersley N.S., Ontiveros M.M., Alcantar C.R. \& Smith B. 2003. Efficacy of ceftiofur tratament of experimental salmonellosis in neonatal calves. Am. J. Vet. Res. 64:918-925.

Garcia K.0. 2010. Infecção experimental de aves de postura (Gallus gallus domesticus) por cepas de Salmonella enterica sorovar Gallinarum (SG), SGNal ${ }^{r}$, SGDcobS e SGDcobSDcbiA: anatomopatologia, hemograma e perfil bioquímico sérico. Dissertação de Mestrado em Patologia Animal, Faculdade de Ciências Agrárias e Veterinárias, Universidade Estadual Paulista, Jaboticabal, SP. 77p.

Godson D.L., Campos M., Attah-Poku S.K., Redmond M.J., Cordeiro D.M., Sethi M.S., Harland R.J. \& Babiuk L.A. 1996. Serum haptoglobin as an indicator of the acute phase response in bovine respiratory disease. Vet. Immunol. Immunopathol. 51:277-292.

Gruys E., Obwolo M.J. \& Toussaint M.J.M. 1994. Diagnostic significance of the major acute phase proteins in veterinary clinical chemistry: A review. Vet. Bull. 64:1009-1018.
Heinrich P.C., Castell J.V. \& Andus T. 1990. Interleukin-6 and the acute phase response. Biochem. J. 265:621-636.

Itoh Y., Hirose K., Miyake M., Khan A.Q., Hashimoto Y. \& Ezaki T. 1997. Amplification of $r f b E$ e $f l i C$ genes by polimerase chain reaction for identification and detection of Salmonella serovar Enteritidis, Dublin and Gallinarum-Pullorum. Microbiol. Immunol. 41:791-794.

Kaneko J.J., Harvey I.W. \& Bruss M.L. 2008. Clinical Biochemistry of Domestic Animals. $6^{\text {th }}$ ed. Academic Press, San Diego. 916p.

Keay G. \& Doxey D.L. 1982. Species characteristics of serum protein demonstrated after agarose gel electrophoresis. Vet. Res. Commun. 5:163270.

Kent J. 1992. Acute phase proteins: Their use in veterinary diagnosis. Brit. Vet. J. 148: 279-282.

Kirk J., Atwill E., Holmberg C., Arana M., Collar C., Ghiardelli D., Higginbotham G., Markagaard G., Mullinax D. \& Wubishet A. 2002. Prevalence of and risk factors for Salmonella in water offered to weaned dairy calves in California. Prev. Vet. Med. 54:169-178.

Milles A.A. \& Misra S.S. 1938. The estimation of the bactericide power of the blood. J. Hyg. 38:732-739.

Rice D.H., Besser T.E. \& Hancock D.D. 1997. Epidemiology and virulence assessment of Salmonella Dublin. Vet. Microbiol. 56:11-24.

Santos R.L., Tsolis R.M., Bäumler A.J. \& Adams L.G. 2002. Hematologic and serum biochemical changes in Salmonella serovar Typhimurium-infected calves. Am. J. Vet. Res. 63:1145-1150.

Smith B.P., Oliver D.G., Singh P., Dilling G., Marvin P.A., Ram B.P., Jang L.S., Sharkov N., Orsborn J.S. \& Jackett K. 1989. Detection of Salmonella Dublin mammary gland infection in carrier cows, using an enzyme-linked immunosorbent assay for antibody in milk and serum. Am. J. Vet. Res. 50:1352-1360.

Smith B.P., Da Roden L., Thurmond M.C., Dilling G.W., Konrad H., Pelton J.A. \& Picanso J.P. 1994. Prevalence of salmonellae in cattle and in the environment on California dairies. J. Am. Vet. Med. Assoc. 205:467-471.

Veling J., Barkema H.W., Schans I., Zijderveld F. \& Verhoeff J. 2002. Herdlevel diagnosis for Salmonella enterica subsp. enterica serovar Dublin infection in bovine dairy herds. Prev. Vet. Med. 53:31-42.

Wallis T.S., Paulin S.M., Plested J.S., Watson P.R. \& Jones P.W. 1995. The Salmonella Dublin virulence plasmid mediates systemic but not enteric phases of salmonellosis in cattle. Infect. Immun. 63:2755-2761.

Weber K. \& Osborn M. 1969. The reliability of molecular weigth determinations by dodecil sulfate-polyacrilamide gel electrophoresis. J. Biol. Chem. 244:4406-4412.

Wray C. \& Sojka W.J. 1981. Salmonella Dublin infection of calves: Use of small doses to simulate natural infections on the farm. J. Hyg. 87:501-509.

Wray C. \& Davies R.H. 2000. Salmonella infections in cattle, p.169-191. In: Wray C. \& Wray A. (Eds), Salmonella in Domestic Animals. CABI Publishing, Oxon.

Zar J.H. 1999. Biostatistical Analysis. $4^{\text {th }}$ ed. Prentice Hall, New Jersey. $663 p$. 